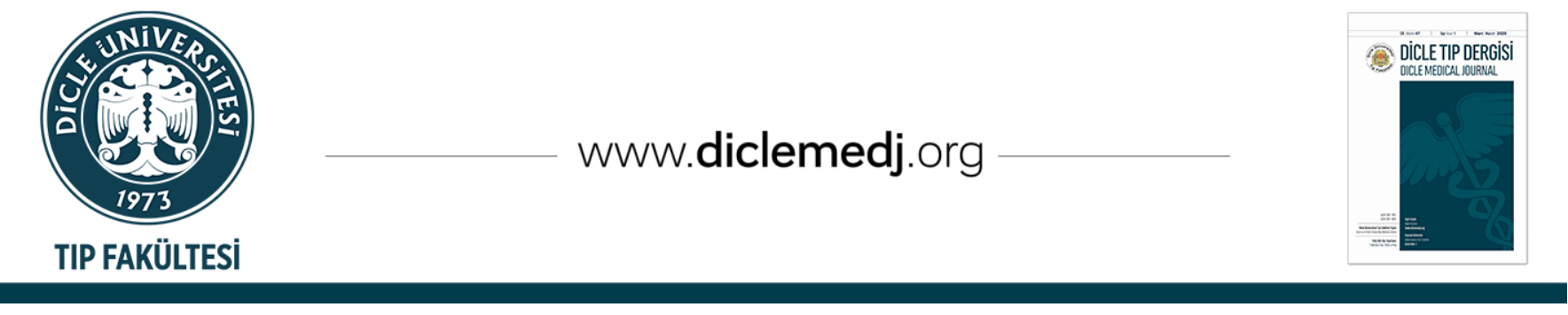

Case Report / Olgu Sunumu

\title{
Ring Chromosome 13, A Rare Case Report
}

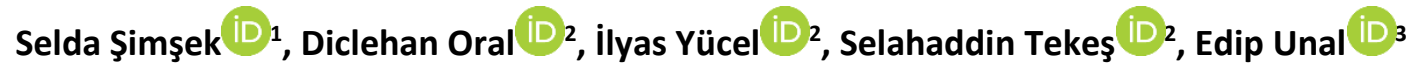 \\ 1 Pamukkale University, Medical Faculty, Departmet of Medical Biology, Denizli, Turkey \\ 2 Dicle University, Medical Faculty, Departmet of Medical Biology, Diyarbakır, Turkey
}

3 Gazi Yaşargil Education Research Hospital, Departmet of Child Health and Diseases, Diyarbakır, Turkey

Received: 13.02.2020; Revised: 20.05.2020; Accepted: 27.05.2020

\section{Abstract}

This case report describes the cytogenetic and molecular characterization of a child with de-novo ring chromosome 13 $[\mathrm{r}(13)]$. The child presented with short stature, growth retardation and a Turner syndrome diagnosis. She was the first case of ring chromosome 13 cytogenetic alteration observed in our laboratory at Dicle University, Turkey. Her chromosomal composition was 46,XX,r(13). FISH (Fluorescence InSitu Hybridization) also confirmed the presence of r(13). A chromosomal microarray analysis using a CytoScan ${ }^{\circledR}$ Optima assay (Affymetrix) detected a $6.3 \mathrm{Mb}$ deletion at 13q33.3q34. This rare case presented the first $\mathrm{r}(13)$ cytogenetic alteration detected in our laboratory.

Keywords: 13q deletion, Ring chromosome 13, karyotype, FISH, microarray 


\section{Ring Chromosome 13, Nadir Bir Olgu Raporu}

\section{Öz}

Bu olgu sunumunda de-novo ring kromozom 13 [r(13)] tespit edilen bir çocuk hastanın sitogenetik ve moleküler açıdan sonuçları değerlendirilmiştir. Hasta kısa boy, büyüme geriliği ve Turner sendromu ön tanısı ile laboratuvarımıza yönlendirilmiştir. Yapılan kromozom analizi sonucu 46, XX, r (13) kromozom kuruluşu tespit edilen hastaya FISH (Floresan InSitu Hibridizasyonu) analizi yapılarak r (13) varlığı teyit edilmiştir. CytoScan® Optima testi (Affymetrix) kullanılarak yapılan kromozomal mikro dizin analizi sonucunda 13q33.3q34'te 6.3 Mb'lik bir delesyon saptanmıștır. Bu nadir olgu, laboratuvarımızda saptanan ilk r (13) sitogenetik değişiklik olması nedeni ile önemlidir.

Anahtar kelimeler: 13q delesyonu, Ring kromozom 13, karyotip, FISH, mikrodizin.

\section{INTRODUCTION}

Deletions of chromosome regions are generally the result of double-stranded chromosome breaks, followed by the loss of the resulting a centric fragments during the next cell division. Such deletions can lead to ring chromosomes ${ }^{1-3}$.

A ring $\mathrm{D}$ chromosome was first described in a male subject in 1962 by Wang et al.4-6. There are considerable phenotypic variations in patients who carry a ring chromosome in either the complete or the mosaic form ${ }^{5}$. Patients with ring chromosome 13 [r(13)] have various phenotypic abnormalities that correspond to specific breakpoints ${ }^{2,7}$.

This case report presents the first instance of de-novo $r(13)$ that has been analysed by our laboratory. We evaluated this rare case using cytogenetic, molecular cytogenetic and molecular techniques.

\section{CASE PRESENTATION}

An 11-month-old female child with short stature, growth retardation and a Turner syndrome diagnosis was referred to the Dicle University, Medical Faculty, Department of Medical Biology for karyotype analysis. The parents provided the child's family history. According to the provided information, the subject was the second child of a couple who had been married for five years. There was no parental consanguinity, and the couple's first child was a healthy three-year-old male.
A detailed clinical examination of the young girl was performed in the pediatrics department, and developmental retardation and unspecified height-shortening was observed. A trans thoracic echocardiogram of the subject was suboptimal due to her agitation, and the results were evaluated as PS (mild). An electrocardiogram (ECG) measured her sinus rhythm heart rate at $107 / \mathrm{min}$. A detailed laboratory analysis revealed the following measurements: TSH $(1.41 \mathrm{ul} / \mathrm{ml})$, free T4 (23.61 $\mathrm{pmol} / \mathrm{l})$, $\mathrm{LH}(0.1 \mathrm{mlU} / \mathrm{ml}), \mathrm{FSH}(2.02 \mathrm{mlU} / \mathrm{ml})$ and oestradiol $(5.00 \mathrm{pg} / \mathrm{ml})$.

A cytogenetic analysis was performed using a Standard peripheral blood culture, the GTG (Giemsa Banding) method and phytohemagglutinin-stimulated lymphocytes. The subject's chromosomal composition was 46, XX, r (13) (Figure 1,2).

Figure 1. Metaphase of the case

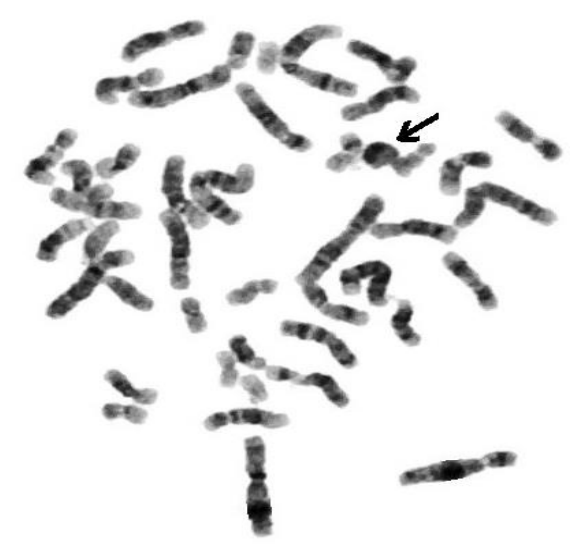

Figure 1. Metaphase of the case 
igure 2. Karyotype of the case.
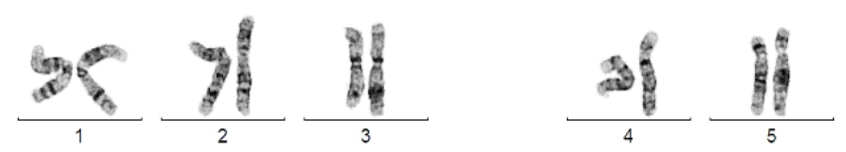

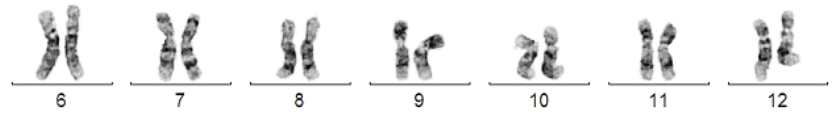

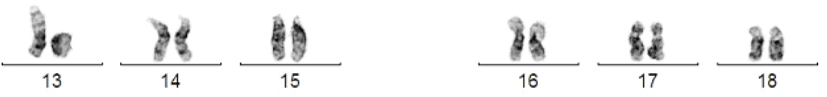

$\frac{88}{19} \cdot \frac{98}{20}$
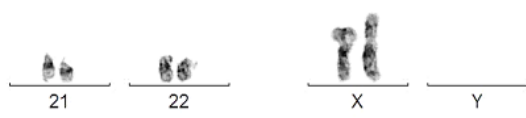

Figure 2. Karyotype of the case

The karyotypes of both parents were normal. A FISH analysis was performed using a whole chromosome staining probe (WCP), according to the Cytocell Standard protocol, and r(13) was confirmed (Figure 3).

Figure 3. FISH image of metaphase using Whole Chromosome Staining probe (WCP) and chromosome 13 was seen as green signal

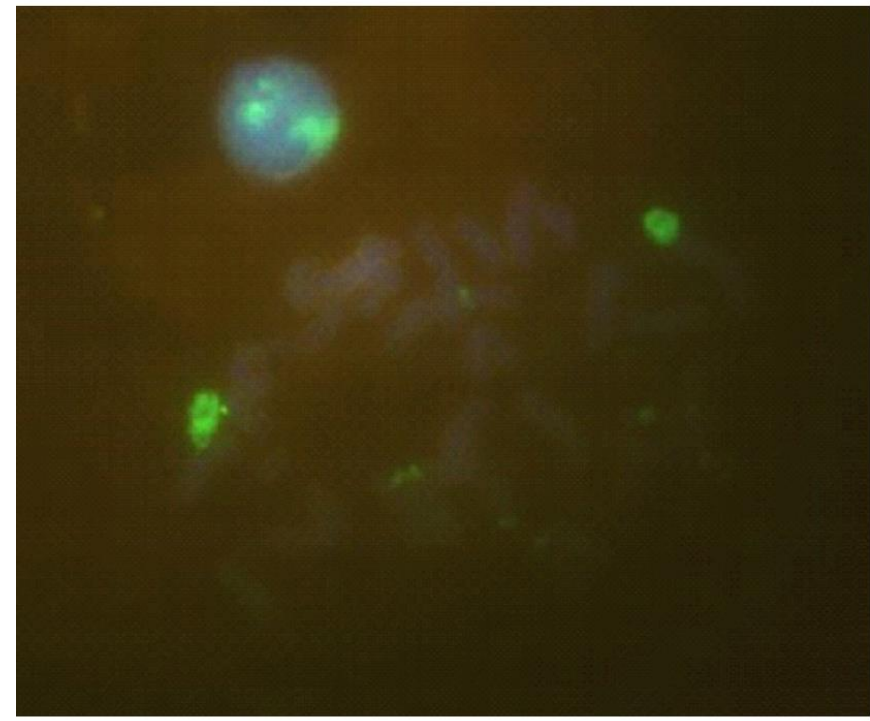

Figure 3. FISH image of metaphase using Whole Chromosome Staining probe (WCP) and chromosome 13 was seen as green signal

A chromosomal microarray analysis using a CytoScan ${ }^{\circledR}$ Optima assay (Affymetrix) detected a $6.3 \mathrm{Mb}$ deletion at 13q33.3q34. This deletion involved the following genes: LIG4 (601837), TNFSF13B (603969), IRS2 (600797), COL4A1 (120130), COL4A2 (120090), CARS2 (612800), ING1 (601566), ARHGEF7 (605477), SOX1 (602148), ATP11A (605868), MCF2L (609499), F7(613878), F10 (613872) PROZ (176895), PCID2 (613713), CUL4A (603137), LAMP1 (153330), ADPRHL1 (610620), TFDP1 (189902), ATP4B (137217), GRK1 (180381), GAS6 (600441), RASA3(605182), CDC16 (603461) and UPF3A (605530).

\section{DISCUSSION}

This report presents the first $r(13)$ case detected by our laboratory in southeast Turkey. GTG banding of the metaphase chromosomes and the corresponding FISH analysis were performed. A terminal deletion was observed in the results of both methods; however, the banding karyotyping and FISH analysis were unable to define the precise breakpoint of the terminal deletion. Further investigation using chromosomal microarray analysis by CytoScan ${ }^{\circledR}$ Optimaassay (Affymetrix) detected a $6.3 \mathrm{Mb}$ deletion on the long arm of chromosome 13 (13q33.3q34).

Martin, Harvey and Pearn presented a study on $\mathrm{r}(13)$ syndrome that provided the detailed clinical and cytogenetic features of three unrelated cases. All these r(13) syndrome cases had breakpoints within the region bounded by bands 13q21 to 13q34 (5).

Brawn et al. reported that patients with interstitial deletions in the long arm of chromosome 13 had widely varying phenotypes. Based on cytogenetic analyses, they postulated that there was a specific region in $13 q 32$ where deletions caused severe malformations, including digital and brain anomalies. To test this hypothesis at the molecular level, they studied chromosome 13 deletions in 17 patients; 5 had severe malformations, while there are 12 had only minor malformations. The results indicated that 
the deletions in all the severely affected patients involved an overlapping region in q32, while the deletions in the mildly affected patients included some, but not all, of this overlapping region. They suggested that the severely malformed 13q- phenotypes resulted from deletions in a critical region of $13 q 32^{8}$.

Liao et al. described a 10-month-old Chinese Han boy who presented with severe mental retardation, congenital bilateral hearing loss and multiple malformations. He had both $\mathrm{r}(13)$ syndrome and 47, XYY syndrome, and his karyotype was 47,XYY,r(13)(p11q34). After further research using high resolution, arraybased, comparative genomic hybridization, a terminal deletion of $8.5 \mathrm{Mb}$ was identified in the long arm of chromosome 13 (13q33.2->q34). Liao et al. suggested that the patient's hearing impairment might be a clinical feature associated with the distal $13 \mathrm{q}$ deletion and the r(13) formation 9 . In addition, Ozsu et al. reported a case with ambiguous genitalia and $r$ $(13)^{10}$.

Minasi et al. described the first postnatal diagnosis of a child from Central Brazil with de novo cytogenetic alterations in 13q; this case was characterized by malformations of the brain, eyes, distal limbs and genitourinary tract, as well as a severe intellectual disability. The subject's karyotype was a constitutive 46,XX,r(13)[77]/45,XX,-13[17]/46,XX,idic $r(13)^{6}$, and a chromosomal microarray analysis detected a $15.39 \mathrm{Mb}$ deletion. They suggested that further studies were needed to define whether genetic haploinsufficiency was associated with each major $13 \mathrm{q}$ deletion anomaly or whether one or more putative genes of the critical regions are contributing to these congenital malformations ${ }^{2}$.

Ping-Chen et al. described prenatal diagnosis and molecular cytogenetic characterization of de-novo mosaic $r$ (13) with fetoplacental chromosomal discrepancy ${ }^{11}$.

\section{CONCLUSION}

Karyotyping is substantial to demonstrate autosomal chromosome anomalies but then the molechular methods should be used to define the exact break point of the terminal deletions.

Congress presented: This case reporte was presented on 26-29 October 2017 in Fethiye at National Medical Biology and Genetics Congress as seen below: S.Simsek, D.Oral, İ.Yücel, S.Tekeş, E.Unal, H.İsi.

The case report, Ring Chromosome 13, XV. National Medical Biology and Genetics Congress, 26-29 October 2017.

Informed Voluntary Consent Form: Consent form was taken from the patient.

Declaration of conflicting Interest: The authors declare that have noconclift of interest.

Financial Disclosure: No financial support was received.

\section{REFERENCES}

1. Nussbaum RL. Thompson and Thompson Genetics in Medicine. Six edition, WB. Saunders Company, 2001: 172-5.

2. Minasi LB, IPinto IP, Almeida J, et al. Postnataldiagnosis of constitutive ring chromosome 13 using both conventional and molecular cytogenetic approaches. Genetics and Molecular Research 2015; 14: 1692-9.

3. Türkyılmaz A, Oral D, Şimşek S, et al. De Novo dengeli 18pter delesyonlu olgu sunumu A casewithdeletion of De Novobalanced 18pter. Dicle Tip Derg. 2009; 36: 316-8.

4. Wang HC, Melnyk J, McDonald LT, et al. Ring chromosomes in human beings. Nature. 1962; 195: 733-4.

5. Martin NJ, Harvey PJ, Pearn JH. The Ring Chromosome 13 Syndrome. Hum Genet. 1982; 61: 18-23.

6. JubergRC, Adams MS, Venema WJ, et al.Multiple Congenital Anomalies Associated 
with a Ring-D Chromosome. J. Med. Genet. 1969: 6; 314.

7. Uwineza A, Pierquin G, Gaillez S, et al. Clinical, Cytogenetic and Molecular Characterization of Two Cases of Mosaic Ring Chromosome13. Genetic Counciling. 2013; 24: 193-200.

8. Brown S, Russo J, Chitayat D, et al. The $13 q-$ Syndrome: The Molecular Definition of a Critical Deletion Region in Band 13q32. Am. J. Hum. Genet. 1995; 57: 859-66.

9. Liao C, Fu F, Zhang L. Ring chromosome 13 syndrome characterized by high resolution array based comparative genomic hybridization in patient with 47, XYY syndrome: a case report. Journal of Medical Case Reports 2011; 5: 99.
10. Özsu E, Mutlu GY, İpekçi $\quad$ B. Ring Chromosome 13 and Ambiguous Genitalia. Journal of Clinical Research in Pediatric Endocrinology. 2014; 6: 122-4.

11. Chen CP, Tsai CH, Chern SR, et al. Prenatal Diagnosis and Molecular Cytogenetic Characterization of Mosaic Ring Chromosome 13. 2013; Gene, 529; 163-8. 